Laith A. JAWAD

Fish systematics

\title{
VARIATION IN MERISTIC CHARACTERS OF A TILAPIAN FISH, TILAPIA ZILLI (GERVAIS, 1848) FROM THE INLAND WATER BODIES IN LIBYA \\ ZMIENNOŚĆ CECH MERYSTYCZNYCH TILAPII, TILAPIA ZILLI (GERVAIS, 1848) ZE ŚRÓDLĄDOWYCH ZBIORNIKÓW WODNYCH LIBII
}

\begin{abstract}
School of Biological Sciences, The University of Auckland, New Zealand
Meristic characters were compared in samples of the tilapian fish, Tilapia zilli (Gervais, 1848), collected from lake Ain Ziana, lake Tawrqa, and Ojala area, Libya. The significant difference in the number of vertebrae and the pectoral fin rays provide an evidence of the existence of three general groups or populations in the three study areas.
\end{abstract}

\section{INTRODUCTION}

Tilapian fish species have been considered an important source of food for humans at least since recorded history began (Bardach et al. 1972). The species of Tilapia zilli (Gervais, 1848) was primarily introduced into certain inland water bodies of Libya for aquaculture purposes and distributed latter on in several other water bodies through these activities.

Meristic characters and the variation that may show have been used as a basic tool in separating populations of different fish species (Seymour 1959; MacCrimmon and Clayton 1985; Al-Hassan 1984, 1987a, b, 1990). Meristic differences between populations of fishes may be influenced by genetic or environmental factors, or both (Bailey and Gosline 1955). Different workers have attributed the differences in meristic characters to environmental factors such as light, temperature and dissolved oxygen during the period from fertilisation to hatching (Taning 1955; Wallace 1973; Kwain 1975). 
This study was undertaken to determine whether the fish species, T. zilli (Gervais, 1848) inhabiting lake Ain Ziana, lake Tawrqa and Ojala private fish ponds represents one homogenous population.

\section{MATERIAL AND METHODS}

Fish specimens were collected from January 1995 to December 1995 from three inland water bodies in Libya. These are lake Ain Ziana (250 specimens), north east of Benghazi city, lake Tawrqa (200 specimens), east of Tripoli city and from a private recreational fish pond at Ojala city ( 300 specimens), $200 \mathrm{~km}$ south of Benghazi city.

Meristic characters examined include number of vertebrae and pectoral fin rays. The remaining fin ray count showed no variation, thus, they are not included in this study. Vertebral counts were made from specimens prepared by boiling the whole fish prior to counting. Vertebral number included the total segments between, but not including, the basioccipital and hypural. Counts of pectoral fin rays were done under a dissecting microscope. Ray counts included all rays.

The two variables were compared using least significant difference (LSD) test (Snedecor and Cochran 1967). The meristic variables were then subjected to cluster analysis (WPGM) using average of distance coefficients (Blackith and Reyment 1971).

\section{RESULTS AND DISCUSSION}

Whatever the mechanism controlling meristic variation in fishes, large meristic differences between populations are usually to develop without some measure of isolation between the populations, as continual interchange of individuals will tend to prevent the development of genetic differences. However, meristic characters may differ on account of environmental differences during early development (Taning 1952). Natural selection will act on such characters and, when isolation is complete, genetic differences between the populations may, in time, develop.

Distribution of the pectoral fin rays and the number of vertebrae are shown in Fig 1. Comparison of the means between the three localities in question showed a significant heterogeneity of the populations indicating that more than one population were represented in the samples. Three groups were distinguished from the cluster analysis (Fig. 2) representing the three populations of $T$. zilli (Gervais, 1848) studied. This suggests different races. In certain instances significant differences were found in meristic counts between fishes from neighbouring streams and among streams within large geographical areas (Nichols 1966). 
The cause of these differences is either genetic or environmental variation under which the fish develop, or a combination of both (MacCrimmon and Clayton 1985; Yokogawa et al. 1989).

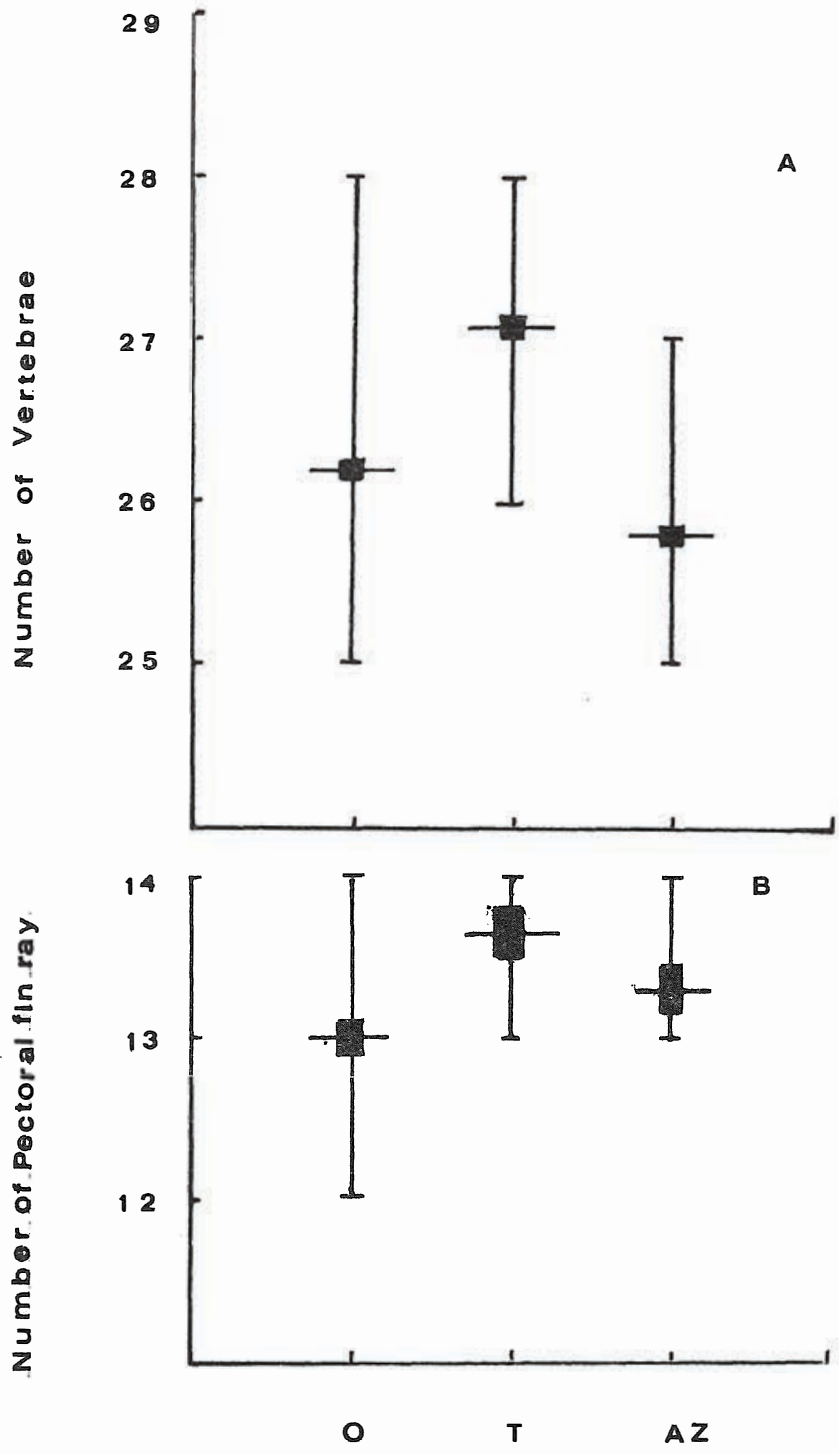

Fig. 1. Variation in (A) number of vertebrae; (B) number of pectoral fin rays of $T i$ lapia zilli Ojala area (O), Tawrqa lake (T), and Ain Ziana lake (AZ). For graphical display of the results obtained by this method, the ranges of meristic characters are shown by vertical lines, the mean by small horizontal lines, which LSD represented by an open bar o each side of the mean 


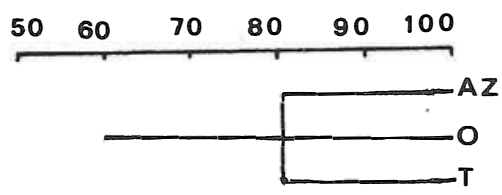

Fig. 2. Dendrogram of the relations among three populations of Tilapia zilli from Ojala (O), Tawrqa lake (T), and Ain Ziana lake (AZ) based on the WPGM clustering procedure of correlation coefficient

The genetic variation cause can be envisaged in the following explanation. The tilapian fish, T. zilli (Gervais, 1848) is an introduced fish in Libya, thus it is highly possible that the fish stock of this species usually used in the aquaculture originated from a genetically different population. On the other hand, the effect of environmental variation is evident in the Mediterranean coasts in general and the Libyan coasts in particular. Several authors reported the adverse environmental conditions along the Mediterranean coasts (Domovic 1992; Meadow 1992; Sellali et al. 1992). And this is also true for the Libyan coasts (Hamouda and Wilson 1992; Magazzu and Angot 1992; Toumi et al., 1992). For Ain Ziana Lake, several preliminary works reported a high concentration of pollutants (Anon. 1977; Guerrie 1978; El-Toumi et al. 1995) and Al-Hassan et al. (Unpublished data) recorded relatively high concentrations of pollutants of different sorts. As to lake Tawrqa, the situation of pollution is different. Here the level of organic matter and hydrocarbon pollution are low and the level of heavy metals from sources other than hydrocarbons is high (Personal observations).

The meristic characters were not always ruled by the genetic factors specially in some seawater fishes (Okamoto 1988; Yokogawa and Taniguchi 1988). Their reports indicate that the meristic counts usually correspond with the genetic differences in some cases, whereas in the other cases, they are not related to the genetic factors. In addition to the possibility of heterogeneous origin of the fish stock used in the aquaculture processes in Libya, variation in the environmental factors occur in the Libyan coasts and the lakes under consideration can not be ignored as a causative agent for meristic characters variation of the fish species in question. 


\section{CONCLUSIONS}

The population of T. zilli (Gervais, 1848) in the eastern part of Libya can be divided into three subpopulations on the basis of the meristic characters e.g. number of vertebrae and pectoral fin ray count. The genetical origin of this introduced fish species and the variation in the environmental factors could be the reasons behind the population subdivision.

\section{REFERENCES}

Al-Hassan L.A.J., 1984: Meristic comparison of Liza abu from Basrah, Iraq and Karkhah River, Arabistan, Iran. Cybium, 8, 3: 107-108.

Al-Hassan L.A.J., 1987a: Comparison of meristic characters of mosquito fish, Gambusia affinis (Baird \& Girard) from Basrah and Baghdad, Iraq. Pakistan J. Zool., 19, 1: 69-73.

Al-Hassan, L.A.J., 1987b: Variations in meristic characters of Nematolosa nasus from Iraqi and Kuwaiti waters. Jap. J. Ichthyol., 33, 4: 422-425.

Anonymous, 1977: Fish farming project in Ain Ziana. Benghazi, Libya. Aquaservice.

Bailey R.M., W. Gosline, 1955: Variation and systematic significance of vertebral counts in the American fishes of the family Percidae. Misc. Publ. Mus. Zool. Univ. Michigan, 93.

Bardach, J.E., J.H. Ryther, W.O. McLarney, 1972: Aquaculture. Wiley-Interscience, New York.

Blackith R.E., R.A. Reyment, 1971: Multivariate morphometrics. Academic Press, New York.

Domovic D., 1992: The source of marine oil pollution with special reference to accidental oil pollution in the Mediterranean. Bull. Mar. Biol. Res. Cent., 9 (B): 179-204.

El-Toumi F.F., S. Bain, M. Adrawi, G.A. Nair, 1995: An ecological approaches to Ain Ziana lagoon, Benghazi, Libya. Gar younis Univ. Int. Rep.

Guerrie A., 1978: Ain Ziana project synthesis report. Part 1. Hydro geological appraisal. Secretariat of Dams and water resources, Benghazi, Libya.

Hamouda M.S., J.C. Wilson, 1992: Levels of heavy metals and total hydrocarbon along the Libyan coastline. Bull. Mar. Biol. Res. Cent., 9 (B):31-43.

Kwain W., 1975: Embryonic development, early growth, and meristic variation in rainbow trout, Salmo gairdneri exposed to combinations of light intensity and temperature. J. Fish. Res. Bd Can., 32: 397-402.

MacCrimmon H.R., R.R. Clayton, 1985: Meristic and morphometric identity of Baltic stocks of Atlantic salmon (Salmo salar). Can. J. Zool., 63: 2032-2037.

Magazzu G. M. Angot, 1992: Dissolved and dispersed petroleum hydrocarbons in Libyan coastal waters. Bull. Mar. Biol. Res. Cent., 9 (B):1-45.

Meadows P.S., 1992: Pollution, conservation and the Mediterranean ecosystem: a perspective view. Bull. Mar. Biol. Res. Cent., 9 (B): 269-298.

Nichols P.R., 1966: Comparative study of juvenile American shad populations by fin-ray and scute counts. US Fish and Wildlife Serv., Special Sci. Rep. Fish., 525.

Okamoto H., F. Yamazaki, S. Mishima, 1988: Genetic divergence among sand lance Ammodytes personatus populations in Japan. Nippon Suisan Gakkaishi, 54, 8: 1297-1304. 
Sellali B., A. Kemoum, R. Tounsi, 1992: Dissolved-dispersed hydrocarbons in the bay of Algeria: Preliminary results. Bull. Mar. Biol. Res. Cent., 9 (B): 163-170.

Seymour A., 1959. Effects of temperature upon the formation of vertebrae and fin rays in young chinook salmon. Trans. Amer. Fish. Soc., 88: 58-69.

Snedecor G.W., W.G. Cochran, 1967: Statistical methods. $6^{\text {th }}$ edition, Iowa State Univ. Press.

Taning A.W., 1952: Experimental study of meristic characters in fishes. Biol. Rev. Cambridge Phil. Soc., 27: 169-193.

Toumi S.C., N.S.Kumar, A.K. El-Hinshery, 1992: Assessment of dissolved and dispersed petroleum hydrocarbons in Libya seawater. Bull. Mar. Biol. Res. Cent., 9 (B): 153-162.

Wallace C.R., 1973: Effects of temperature on developing meristic structures. Trans. Amer. Fish. Soc., 102: 142-145.

Yokogawa K., N. Taniguchi, 1988: Morphological and genetic differences between artificial brood seeds and natural bred seeds of red sea bream for pennet culture. Bull. Kagawa Pref. Fish. Exp. Stn, 3: 31-42.

Yokogawa K., N. Taniguchi, T. Mukai, 1989: Morphological and genetic differences between Japaneese and Korean black rockfish, Sebastes inermis. Bull. Mar. Sci. Fish., Kochi Univ., 11: 89-94.

Laith A. JAWAD

\section{ZMIENNOŚĆ CECH MERYSTYCZNYCH TILAPII, TILAPLA ZILLI (GERVAIS, 1848) ZE ŚRÓDLĄDOWYCH ZBIORNIKÓW WODNYCH LIBII}

\section{STRESZCZENIE}

Porównano cechy merystyczne tilapii, Tilapia zilli (Gervais, 1848) z trzech rejonów; jezioro Asin Ziana, jezioro Tawrqa i stawy w okolicy Ojala w Libii. Ustalono, że ryby z tych trzech prób wykazywały statystycznie istotne różnice w liczbie kręgów oraz promieni płetw piersiowych. Jest to dowodem istnienia trzech grup lub populacji we wspomnianych trzech rejonach badawczych.

Received: 26 January 2000

Author's address:

Laith A. Jawad

School of Biological Sciences

The University of Auckland, New Zealand

Private Bag 92019 